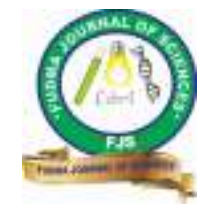

FUDMA Journal of Sciences (FJS)

ISSN online: $2616-1370$

ISSN print: 2645 - 2944

Vol. 4 No. 2, June, 2020, pp $658-672$

DOI: https://doi.orq/10.33003/fis-2020-0402-240

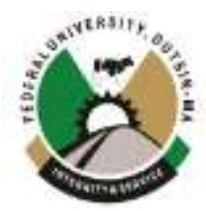

\title{
PRODUCTION AND PERFORMANCE APPRAISAL OF BIODIESEL DERIVED FROM USED COOKING OIL ON COMPRESSION IGNITION ENGINE
}

\author{
${ }^{1}$ Suleimana, I. A., ${ }^{\text {*1 Abubakar, S., }}{ }^{1}$ Kaisan, M. U., ${ }^{2}$ Magaji, S., ${ }^{1}$ Abubakar, A. S., ${ }^{3}$ Shitu, S., ${ }^{1}$ Ajunwa, I., \\ ${ }^{1}$ Ibrahim, I. U. and ${ }^{4}$ Umaru, S. \\ ${ }^{1}$ Department of Mechanical Engineering, Ahmadu Bello University, Zaria, Nigeria. \\ ${ }^{2}$ Ibrahim Shehu Shema Center for Renewable Energy Research, Umaru Musa Yar'adua University, Katsina. Nigeria. \\ ${ }^{3}$ Department of Applied Biology, College of Science and Technology, Kaduna Polytechnic, Kaduna, Nigeria. \\ ${ }^{4}$ Air Force Institute of Technology, Kaduna, Nigeria.
}

*Corresponding Author's Email: abubakarshitu88@gmail.com

\begin{abstract}
The present study is concerned with the production of biodiesel produced from used cooking groundnut oils using alkali trans-esterification reaction. Gas chromatography-mass spectrometry (GC-MS) and Fouriertransform infrared spectroscopy (FTIR) analyses were carried out on the biodiesel produced and the presence of methyl esters and their various functional groups were detected. The Physico-chemical properties of the biodiesels produced were also carried out and most of the properties conformed to ASTM standards. The biodiesel samples were tested in a 165F- Horizontal Single Cylinder Direct Injection Diesel Engine at Bayero University Kano (BUK), Kano State, Nigeria, investigating parameters such as: Brake power, Specific fuel consumption and Brake mean effective pressure. The exhaust gas was analysed in an NHA-506EN automotive gas analyzer, from Nigerian Institute of Transport Technology, Zaria, Kaduna State, where parameters such as hydrocarbon (HC), nitrogen oxide (NOx), carbon monoxide (CO) and carbon (IV) oxide $\left(\mathrm{CO}_{2}\right)$ were all analyzed. The results showed that the oil from frying yam yielded $87.5 \%$ while that from frying fish yielded $94 \%$ and the biodiesels produced conformed to most of the Physico-chemical properties according to the ASTM standards. Also, the engine results demonstrated that there was improved brake power and mean effective pressure but the specific fuel consumptions were higher than that of the control sample. Lastly, the exhaust gas emissions results showed that there were significant reductions in carbon monoxide ( $\mathrm{CO}$ ), nitrogen oxide (NOx), carbon IV oxide $\left(\mathrm{CO}_{2}\right)$ and hydrocarbon emissions showing us that biodiesel is more eco-friendly.
\end{abstract}

Keywords: biodiesel, used cooking oil, ignition engine, alkali trans-esterification

\section{INTRODUCTION}

Insufficient energy is a major factor responsible for the setback of industrialization in developing economies, especially in Nigeria. Recently in Nigeria, pipeline vandalism has been responsible for the decrease in electricity supply with economic hardship. Oil spills, diesel and greenhouse gas emissions are the primary cause of health and environmental challenges in the society (Okere, 2016). Energy shortage across the globe has necessitated the search for a viable and sustainable source (Chang, et al., 2013). According to Roger (2014), diesel fuel and other greenhouse gas emissions are potential causative agents of most chronic diseases such as chronic cancer, heart attack and arrhythmias which often leads to an untimely death. These consist of carbon IV oxides $\left(\mathrm{CO}_{2}\right)$, carbon II oxides $(\mathrm{CO})$ sulfur IV oxides $\left(\mathrm{SO}_{2}\right)$, oxides of Nitrogen ( $\left.\mathrm{NOx}\right)$ and Polyaromatics Hydrocarbons (PAHs), Ozone $\left(\mathrm{O}_{3}\right)$ and Particulates Matters (PM).

In Nigeria, the rate at which energy demand is increasing is very alarming. To meet this increased demand in energy, alternative energy sources should be researched.

A biofuel is a form of fuel derived from plant and animal oils; it can be produced through agricultural and biological processes such as fermentation and anaerobic digestion as a variant from geological processes in the formation of fossil fuel. The common biofuels are mostly ethanol and biodiesel (Roos, 2012).

Trans-esterification method has been widely used to produce biodiesel. It is essentially a chemical process where vegetable oils and fats react with alcohol to produce fatty acid alkyl esters and glycerol. The most common catalyst used to enhance the production process is sodium and potassium hydroxide, sodium methylate and methanol (Anita and Dawn, 2010). Methanol offers several advantages over other catalysts such as low cost, ease to react with vegetable oil and the ease at which $\mathrm{NaOH}$ dissolves in it. The transesterification method requires a specific molar ratio of alcohol to triglycerides in which 3:1 was widely reported. The ratio can be higher for maximum yield at the 
expense of other factors (Aydin et al., 2012; Raja et al., 2011). The triglycerides react with alcohol using a particular catalyst under controlled temperature for a certain period. Alkyl esters and glycerin are obtained as the final yield. The alkyl esters are desirable and the glycerin is a byproduct (Jaichandar and Annamalai, 2011). The used cooking oil produced via transesterification was appraised based on some important physico-chemical properties. The most common examples of physicochemical properties of methyl ester are flash point, kinematic viscosity, total sulfur, copper strip corrosion, moisture contents, carbon residue, acid value, total glycerol and distillation profile (Gerpen et al., 2004).

Many used cooking oils from restaurants, canteens and street sellers are often dumped into the streets which leads to the pollution of the environments. One of the ways of treating these used oils is by converting them to biodiesel and research is limited in this regard (Kawentar, 2013). Han, F. F. B., \& Alrabadi, S. (2018) produced biodiesel from waste cooking oil using a Jordan Zeolite catalyst. A yield of about $95 \%$ was recorded and the properties of the biodiesel conform to the ASTM standard. Jacobson, et al., (2008) assessed the suitability of various catalysts to produce biodiesel from used cooking oil. The yield could reach 98 wt. \%. Gashaw, A. and Abile, T. (2014) provided an overview of biodiesel production methods and highlighted some important factors influencing the production of biodiesel. Biodiesel produced from various feedstock has similar properties with the mineral diesel fuel and could serve as a reliable substitute to diesel oil. Recently, liquid fuels like biodiesel obtained from used cooking oil which is mainly produced via the trans-esterification process have been

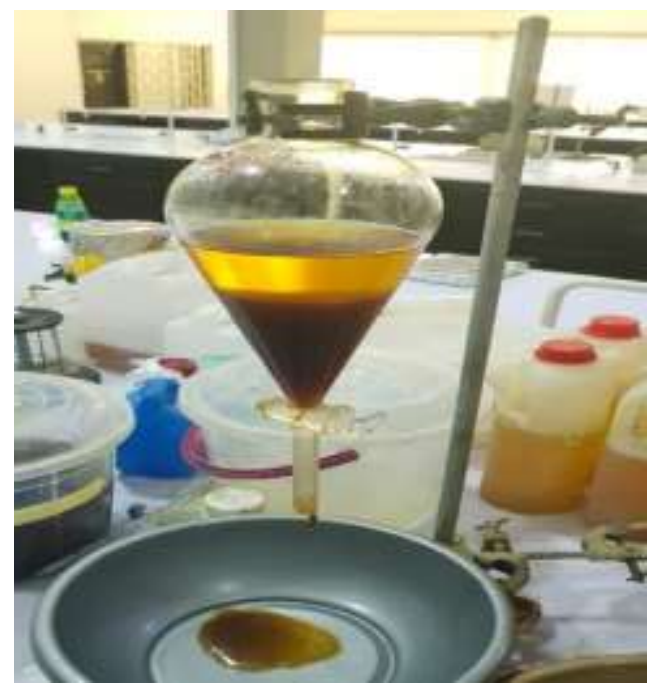

Plate 1: Separation of biodiesel

Gas chromatography - mass spectrometry (GC-MS)

The biodiesel fuel samples were analyzed using Agilent technologies (7890A) GC-MS equipment to identify the fatty acid methyl ester composition in the different used cooking oils identified as one of the good alternative to mineral diesel. However, the available biodiesel comes mainly from vegetable oils and animal fats, problem exists that the feedstock strongly competes with edible materials and the yield for the non-edible is not appreciable (Gashaw and Abile, 2014). Thus, this research is aimed at utilizing the used cooking oils obtained from household activities to investigate its performance and emissions behaviour in a diesel engine.

\section{MATERIALS [b1]AND METHODS}

\section{Production of biodiesel}

The used cooking oil from frying yam and the used cooking oil from frying fish were bought from NIHARI restaurant Samaru Branch; biodiesels were produced from each sample through an alkali transesterification reaction. A mass of (1.44 g[b2][WU3]) hydroxide $(\mathrm{NaOH})$ was added to $99 \mathrm{ml}$ of methanol and were both kept at a temperature of $60{ }^{\circ} \mathrm{C}$ before been stirred with a hot plate and a magnetic stirrer for about an hour then poured into a separating funnel (Kaisan et al., 2017 a.). After three hours when no clear separation occurred, the mixture was left for another 24-hours, two layers were formed: glycerol and biodiesel (Zhang et al., 2003). The washing process was then commenced by introducing water to the mixture until the biodiesel was completely separated and bottled in a well labeled bottle termed sample A for the biodiesel produced from used cooking oil for frying yam. The same procedure was carried out for the used cooking oil from frying fish and the biodiesel gotten was termed as sample B. Plate 1 and 2 [H4]depicts the biodiesel production process.

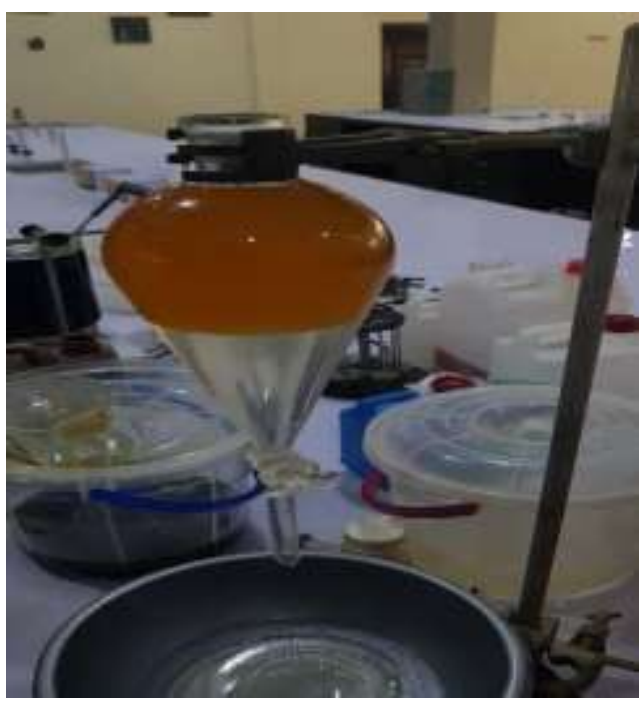

Plate 2: Washing of biodiesel

at the Multi-User Laboratory, Department of Chemistry, Ahmadu Bello University Zaria.[b5]

Fourier-transform infrared spectroscopy (FTIR)

FTIR analysis was employed as a fast and reliable technique for 
the quantification of fatty acid methyl ester functional group in the produced biodiesel. Also, the FTIR was carried out at the Multi-User Laboratory, Department of Chemistry, Ahmadu Bello University Zaria using 5977B MSD CARY 630 FTIR equipment.[b6]

Free fatty acid content (FFA)

Free fatty acid is defined as the percentage of fatty acid of specified molecular weight. The fatty acid is expressed as a milliliter of sodium hydroxide solution of specified normality, which will neutralize the fatty acid in $100 \mathrm{~g}$ of test oil sample. The Free fatty acid is a direct function of acid value. The acid number and the FFA of the samples were determined. The acid value were calculated from equation (1[H7]) below as stated by Kaisan et al., (2017 a[b8]) and Kaisan et al., 2014.

Acid value $=\frac{5.61 \times T}{w}$

Where $\mathrm{T}=$ volume in $\mathrm{ml}$ of $0.5 \mathrm{M} \mathrm{NaOH}$ required for titration; $\mathrm{W}=$ weight in gram for sample taken. The FFA is half of the acid value. The FFA value for sample A was 2.2, while that of sample was 0.8 .

\section{Blending}

The blending of the biodiesel fuels produced to pure fossil diesel fuel was done in the ratio of 20:80 and the biodiesel fuel and pure fossil diesel fuel samples were kept for control purposes. The biodiesel blend from sample A was denoted as sample A B20 and the biodiesel blend from sample B was denoted as sample B B20 while the pure biodiesel sample from used oil from frying yam was denoted as sample A B100 and the pure biodiesel sample from used oil from frying fish was denoted as sample B, B100 and finally, the pure fossil diesel was denoted as $\mathrm{B} 0$.

Determination of physico-chemical properties of the fuel samples

The following properties were determined in accordance to the ASTM D6571 standard for the biodiesel produced from the used cooking oils;

The calorific value

We used bomb calorimeter to note the calorific value of the biodiesel. A quantified amount of the fuel was placed in the crucible. The crucible was then placed over a ring and a fine magnesium wire touching the fuel sample was stretched across the electrodes. The lid was firmly screwed on and $\mathrm{O}_{2}$ at $25 \mathrm{~atm}$ pressure was contained in the bomb. Thereafter, the initial temperature was noted. A battery source of $6 \mathrm{~V}$ was connected

Table 1: ASTM Standard for testing biodiesel

\begin{tabular}{lll}
\hline STANDARD TEST METHOD & ASTM D6751 REQUIREMENTS & ASTM D6751 TESTING CODE \\
\hline Flash Point & $130{ }^{0} \mathrm{C} \mathrm{min}$ & ASTM D 93 \\
Kinematic Viscosity & $40^{\circ} \mathrm{C}, 1.9-6.0 \mathrm{~mm}^{2} / \mathrm{s}$ & ASTM D 445 \\
Cetane Number & $47, \mathrm{~min}$ & ASTM D 613 \\
Cloud Point & Report in ${ }^{0} \mathrm{C}$ & ASTM D 2500 \\
Acid Number & $0.80 \mathrm{mg} \mathrm{KOH} / \mathrm{g}, \mathrm{max}$ & ASTM D 664 \\
Density & $>0.878 \mathrm{~kg} / \mathrm{m}^{3}$ & ASTM D 1298 \\
Pour Point & Report in ${ }^{0} \mathrm{C}$ & ASTM D 97 \\
\hline
\end{tabular}

to the electrodes thereby completing the circuit. The source was then put on, the fuel in the crucible burnt with heat released. The heat released raised the temperature of the water, and the maximum temperature realized was noted (Kaisan et al., 2017 a).

Cetane number

A portable cetane/octane meter was used to determine the cetane number of the fuel based on ASTM D613 guideline. This approach was utilized to ascertain the fuel cetane number rating. The meter scale ranges from 0 - 100 (Kaisan et al., 2017a[b9]).

\section{Flash point}

The flash point of the biodiesel was determined by the ASTM D93 method using a Pensky -Martens closed-cup tester. The determination of the flash point of biodiesel was done in a temperature range of 60 to $190{ }^{\circ} \mathrm{C}$ with an automated PenskyMartens closed-cup apparatus according to the standard method of testing flash point. The flash point determination was carried out by heating a sample of the fuel in a stirred container and passing a flame over the surface of the liquid (Kaisan et al., 2017 a).

\section{Kinematic viscosity}

The kinematic viscosity of the fuel samples was determined in accordance with the ASTM D445 standard. This will involve using a calibrated Viscometer with a calibration constant of 0.1057 to determine the viscosity at $40{ }^{\circ} \mathrm{C}$.

\section{Specific gravity}

To measure the specific gravity of the fuel, a Fisher brand hydrometer (size 0.795-0.910, accuracy 0.001) was used. The procedure adopted was in accordance with Kaisan et al., (2017 $\mathrm{a}[\mathrm{b} 10])$.

\section{Cloud point}

The cloud point was determined in accordance with the ASTM D2500 standard. This method necessitate that the fuel be transparent in layers of $40 \mathrm{~mm}$ thickness This test method covers only petroleum products and biodiesel fuels that are transparent in layers $40 \mathrm{~mm}$ in thickness, and the cloud point value be less than $49{ }^{\circ} \mathrm{C}$.

\section{Pour point}

The pour point was determined in accordance with the ASTM D97 standard method.

The summary of some standard code requirements and methods for testing these properties are listed according to American Society for Testing and Materials, ASTM D 6751 in Table 1.0 (Gerpen et al., 2004).

(Gerpen et al., 2004) 


\section{Engine test and exhaust gas analysis}

Some parameters of the engine performance such as: brake specific fuel consumption, brake power, brake thermal efficiency and exhaust gas temperature as well as the emission characteristics were investigated in a horizontal single cylinder direct injection diesel engine run on biodiesel fuel made from used cooking oils in accordance with Kaisan et al.,(2017 b) method. The engine was tested under full loading conditions at varying torques of $10 \mathrm{~N}-\mathrm{m}, 6 \mathrm{~N}-\mathrm{m}$ and $2 \mathrm{~N}-\mathrm{m}$ for each of the blends. The exhaust gas analysis was achieved by using the NHA-506EN automotive gas analyzer, the exhaust gas was passed into the analyzer through a probe link to the condensation trap and to the particulate filter where the gas particles were removed before they were passed into the analyzer's sensor chamber where the result values of; carbon dioxide $\mathrm{CO}_{2}$, carbon monoxide $\mathrm{CO}$, nitrogen oxide $\mathrm{NOx}$ and hydrocarbon were recorded.

\section{Engine performance parameters}

Several factors play an important role in the performance of an engine, hence an engine is selected based on certain criteria but the considerations often being its power/speed characteristics. The performance of an engine can be determined if some characteristics or parameters of such engines can be evaluated. Hence, if some of these parameters are known, there will be an opportunity to compare the performance of an engine type to the other. The engine parameters are being obtained by measuring the qualities concerned while the results are mostly represented in the form of performance curves (Adeyemo et al., 1998). In this literature, the major parameters considered were: brake power, brake mean effective pressure, thermal efficiency, brake thermal efficiency, specific fuel consumption and diesel engine emissions. The expressions for these parameters are given below:

-Brake power is mathematically given by Eastop and Abundance
McConkey, (2009) as;

$\mathrm{Bp}=2 \pi \mathrm{NT}$

(2[H11])

Where, Torque $(\mathrm{T})$ is given as:

$\mathrm{T}=\mathrm{W} \times \mathrm{R}$

Where $\mathrm{T}=$ Torque, in Newton meter $(\mathrm{Nm}), \mathrm{N}=$ rotational speed $(\mathrm{rpm}), \mathrm{bP}=$ brake power $(\mathrm{kW}), \mathrm{W}=$ Load on dynamometer power $(\mathrm{N}), \mathrm{R}=$ arm radius of the dynamometer power $(\mathrm{m})$.

Brake mean effective pressure (Bpmef) is given by Eastop and McConkey, (2009) as:

$\mathrm{Bp}_{\text {mef }}=\mathrm{bP} 60 / \mathrm{LANK}$

Where $\mathrm{bP}=$ Brake Power $(\mathrm{W}), \mathrm{A}=$ Area of the piston $\left(\mathrm{m}^{2}\right), \mathrm{N}=$ Rotational Speed (rpm), K=Number of Cylinders, $\mathrm{L}=$ Stroke length (m)

-Brake thermal efficiency ( $\left.\prod \mathrm{mbTh}\right)$ is given by Kumar, (2013) as:

$\eta_{\mathrm{mbTh}}=\mathrm{bP} / \mathrm{m}_{\mathrm{f}} \times \mathrm{Q}_{\mathrm{net}, \mathrm{v}}$

Where $\mathrm{m}_{\mathrm{f}}=$ fuel consumption rate $(\mathrm{kg} / \mathrm{s}$ or $\mathrm{kg} / \mathrm{hr}), \mathrm{Q}_{\text {net, }}=$ net calorific value of the fuel $(\mathrm{kJ} / \mathrm{kg}), \mathrm{bP}=$ brake power $(\mathrm{kW})$

Specific fuel consumption (SFC) is given by (Kumar, 2013) as: $\mathrm{SFC}=\mathrm{m}_{\mathrm{f}} / \mathrm{bP}$

Where $\mathrm{SFC}=(\mathrm{kg} / \mathrm{kWhr}), \mathrm{M}_{\mathrm{f}}=$ fuel consumption rate $(\mathrm{kg} / \mathrm{hr})$

\section{RESULTS AND DISCUSSIONS}

Gas chromatography and mass spectroscopy (GC-MS) results

The results of methyl esters percentage contents of the biodiesel products were analyzed by the Gas Chromatrography and Mass Spectroscopy (GC-MS) of the biodiesel produced from used cooking oil from frying yam as "sample A" and used cooking oil from frying fish as "sample B". The interpretation of the peaks of the chromatogram was given in figures 1||[H12]and 2, paying more attention to the methyl esters present in each chromatogram only.

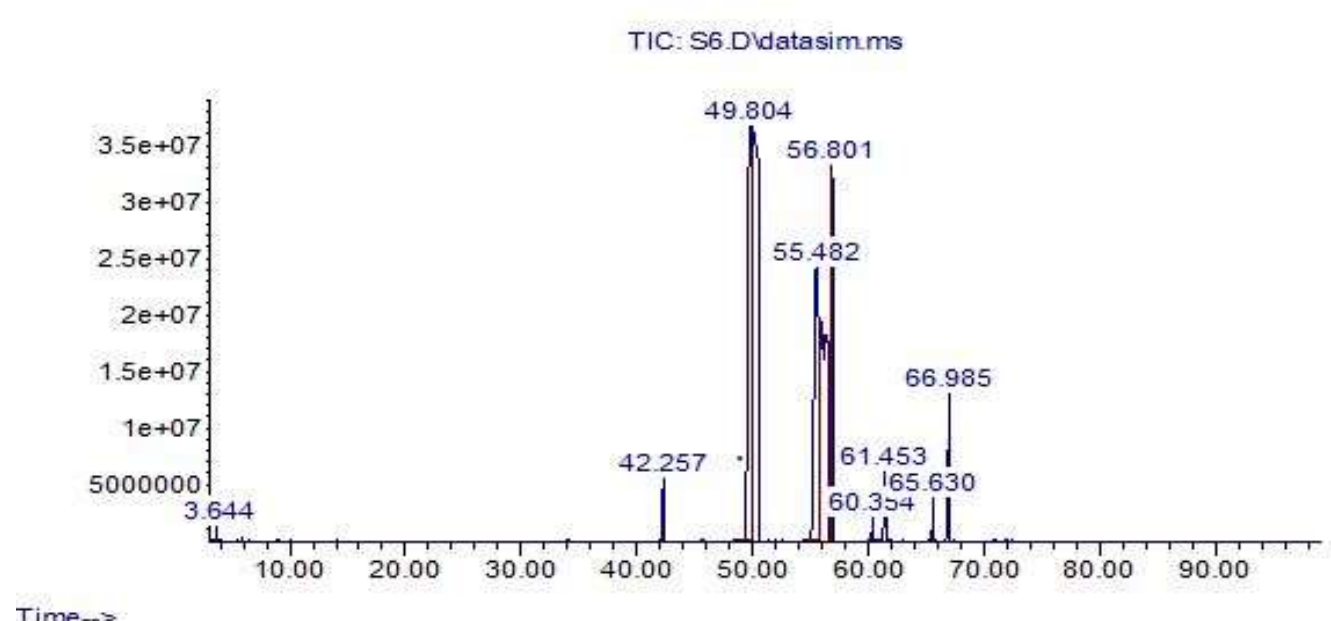

Time- $\rightarrow$

Figure 1: GC-MS Chromatogram of sample A 


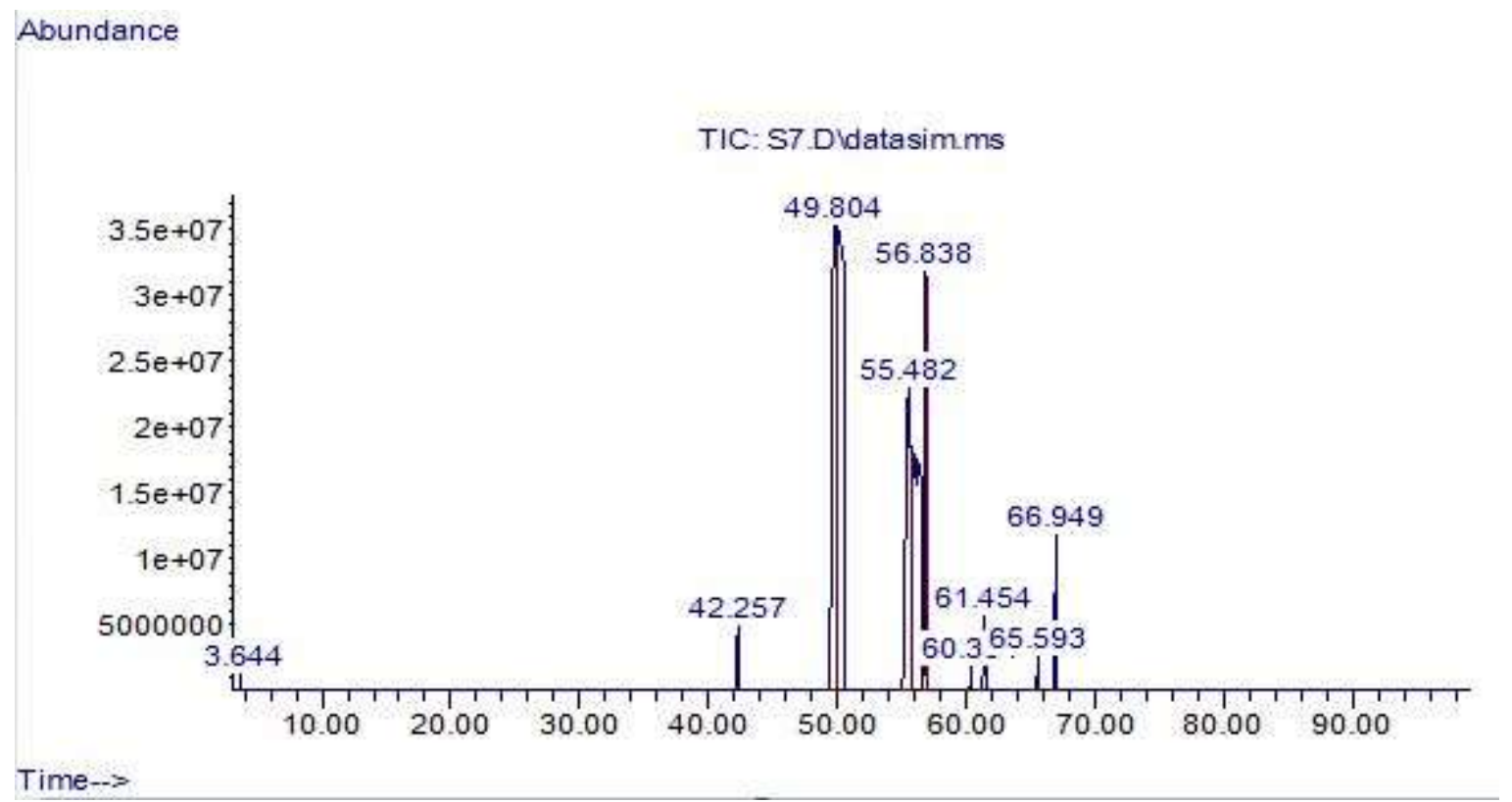

Figure 2: GC-MS Chromatogram of sample B

\section{Sample A methyl ester}

From figure 1 [H13], the methyl ester compositions of biodiesel produced from Sample A confirmed the presence of 9Octadecenoic acid methyl ester $\left(\mathrm{C}_{19} \mathrm{H}_{36} \mathrm{O}_{2}\right)$, Heptadecanoic acid, 16-methyl- methyl ester $\left(\mathrm{C}_{19} \mathrm{H}_{38} \mathrm{O}_{2}\right), 4,7,10,13,16,19$ Docosahexaenoic acid methyl ester, $\left(\mathrm{C}_{23} \mathrm{H}_{34} \mathrm{O}_{2}\right), 5,8,11,14,17-$ Eicosapentaenoic acid methyl ester, $\left(\mathrm{C}_{21} \mathrm{H}_{32} \mathrm{O}_{2}\right)$, and 13Docosenoic acid, methyl ester, $\left(\mathrm{C}_{23} \mathrm{H}_{44} \mathrm{O}_{2}\right)$. Their respective percentages are: $27.81 \%, 9.77 \%, 1.36 \%, 0.42 \%$ and $4.75 \%$. The profile revealed that, 9-Octadecenoic acid methyl ester $\left(\mathrm{C}_{19} \mathrm{H}_{36} \mathrm{O}_{2}\right)$ dominate the mixture with a percentage of $27.81 \%$. The results shown in figure 1 indicate that, the most abundant ester in Sample A is mono saturated methyl octadecanoate. It is an important compound responsible for the stability of the biodiesel, this is because, a higher degree of unsaturation in the fatty acid methyl esters limits its suitability for use as a fuel due to high polymerization tendency, which is caused by peroxidation (Bamgboye and Hensen, 2008). The esters present in Sample A is similar to that of the work of Kaisan et al., (2017 b).

Sample B methyl ester

From figure 2, the methyl ester composition of biodiesel produced from Sample B confirmed the presence of Pentadecanoic acid, 14-methyl-methyl ester $\left(\mathrm{C}_{17} \mathrm{H}_{34} \mathrm{O}_{2}\right)$, 9Octadecenoic acid $(\mathrm{Z})$-, methyl ester $\left(\mathrm{C}_{19} \mathrm{H}_{36} \mathrm{O}_{2}\right)$, Heptadecanoic acid, 16-methyl-, methyl ester $\left(\mathrm{C}_{19} \mathrm{H}_{38} \mathrm{O}_{2}\right)$, Methyl 9eicosenoate $\left(\mathrm{C}_{21} \mathrm{H}_{40} \mathrm{O}_{2}\right)$ and Methyl 11-docosenoate $\left(\mathrm{C}_{23} \mathrm{H}_{44} \mathrm{O}_{2}\right)$. Their respective percentages are: $37.87 \%, 37.87 \%, 13.40 \%$, $1.96 \%$ and $4.76 \%$. The profile shows that, Pentadecanoic acid, 14-methyl-methyl ester $\left(\mathrm{C}_{17} \mathrm{H}_{34} \mathrm{O}_{2}\right)$ and 9-Octadecenoic acid methyl ester $\left(\mathrm{C}_{19} \mathrm{H}_{36} \mathrm{O}_{2}\right)$ are the predominant compounds in the mixture having the highest percentages of $37.87 \%$. The results in figure 2|[H14]indicate that, the most abundant ester in Sample $\mathrm{B}$ is mono saturated methyl octadecanoate. It is a very good compound that has the tendency of assigning stability to the biodiesel, this is because, a higher degree of unsaturation in the fatty acid methyl esters limits its suitability for use as a fuel due to high polymerization tendency, which is caused by peroxidation (Bamgboye and Hensen, 2008). The results of our findings is in line with the work of Kaisan et al., (2017 b).

Fourier transform infrared spectroscopy (FTIR) analysis resul[b15] t[WU16]s

The FTIR analysis results of the two samples were discussed in this section. 


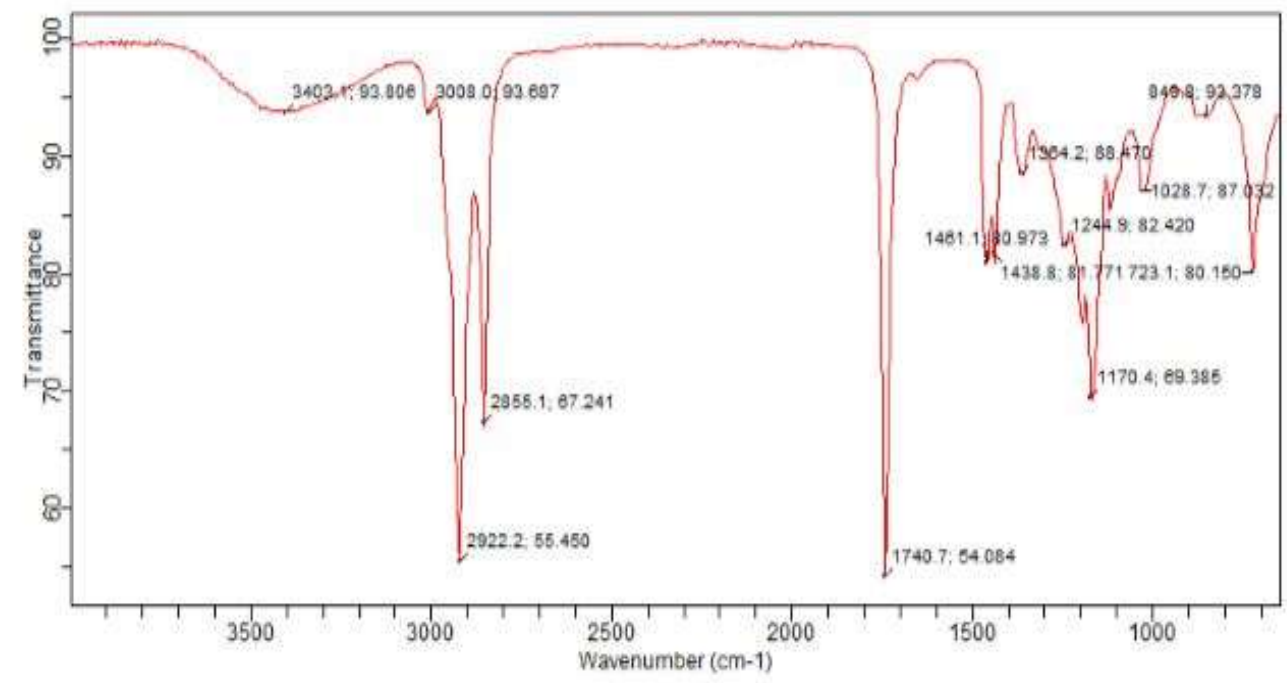

Figure 3: FTIR Analysis of sample A

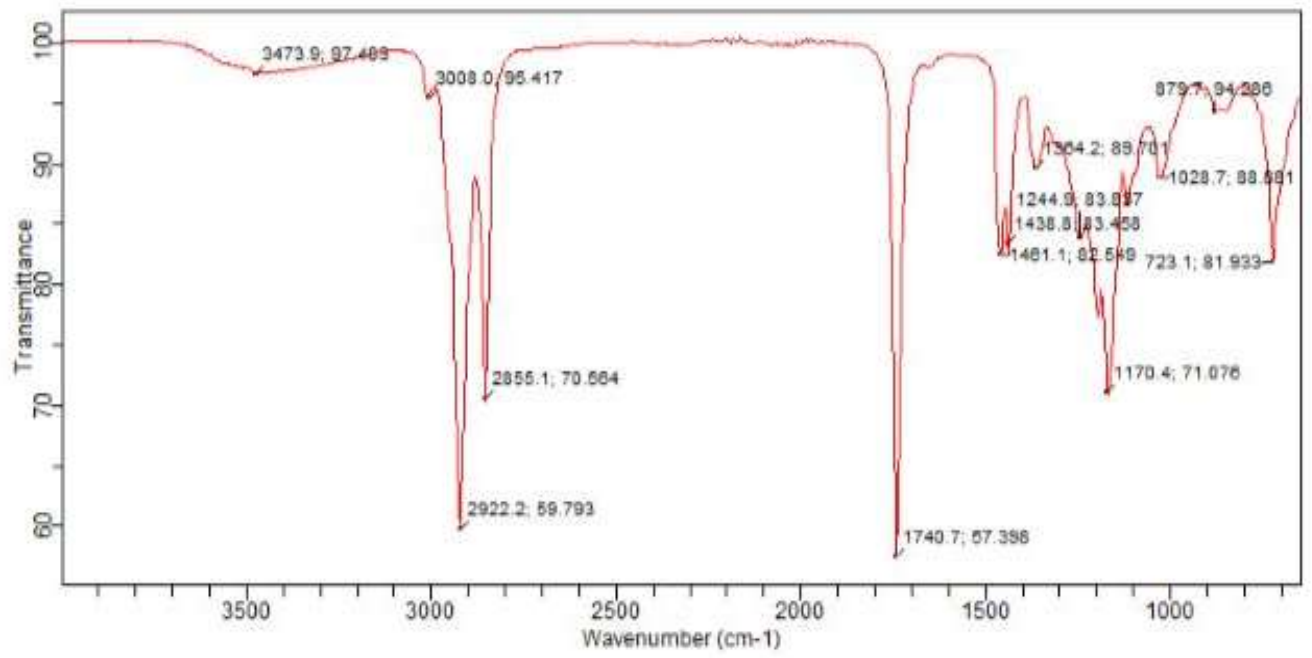

Figure 4: FTIR Analysis of sample B

\section{FTIR Analysis of samples A and B}

FTIR results from figure 3 and 4 clearly demonstrated the transformation of used cooking oils into biodiesel. The response of the functional groups was characterized by observing the transmission of infrared radiations and comparing it with known standards in order to identify the type and the nature of functional groups present. And the results show that the biodiesel produced is stable. The results are in line with the work of Ndana et al., (2016). [b17]

Results of the physico-chemical properties of biodiesel from samples $A$ and $B$

The results of the physico-chemical properties of the biodiesel produced from sample A and sample B are presented in the figures below, paying attention to density, kinematic viscosity, pour point, flash point, cetane number and cloud point.

\section{Kinematic viscosity}

Figure 5 shows the kinematic viscosity of all the biodiesels under consideration. The kinematic viscosity of all the biodiesel samples reviewed fall within the ASTM D455 standards. These results conform to most of the kinematic viscosities obtained by Kaisan et al., (2017 a) and Han \& Alrabadi, (2018). 


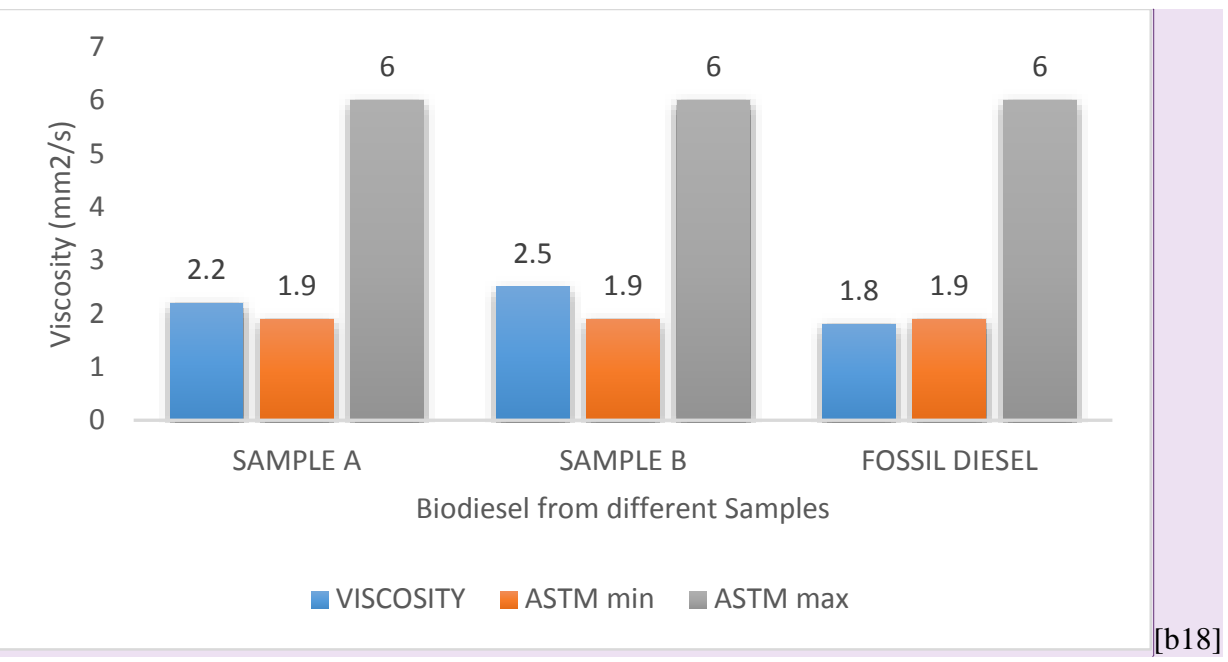

Figure 5: Kinematic viscosities of different biodiesel samples

\section{Density}

The densities of all the biodiesel samples depicted in figure 6 show that the densities of all the biodiesel samples are within the range of the ASTM standard. These results are in line with that of the works of Han \& Alrabadi, (2018) and Kaisan et al., (2017 a).

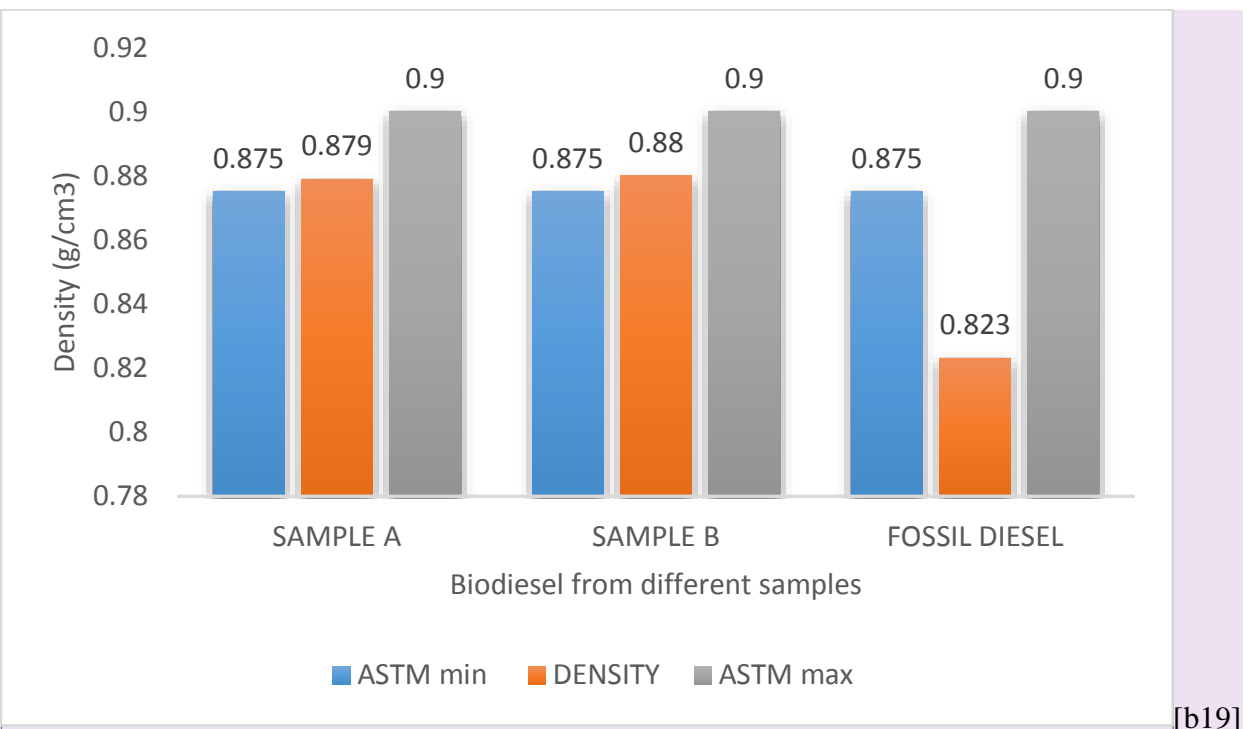

Figure 6: Densities of the biodiesel samples

\section{Flash point}

Figure 7 represents the flashpoint values of the biodiesels samples A and B. The flash points of all the biodiesel from both samples fall with the ASTM D93 range. They conform with the flash point values of Kaisan et al. (2017 a). 


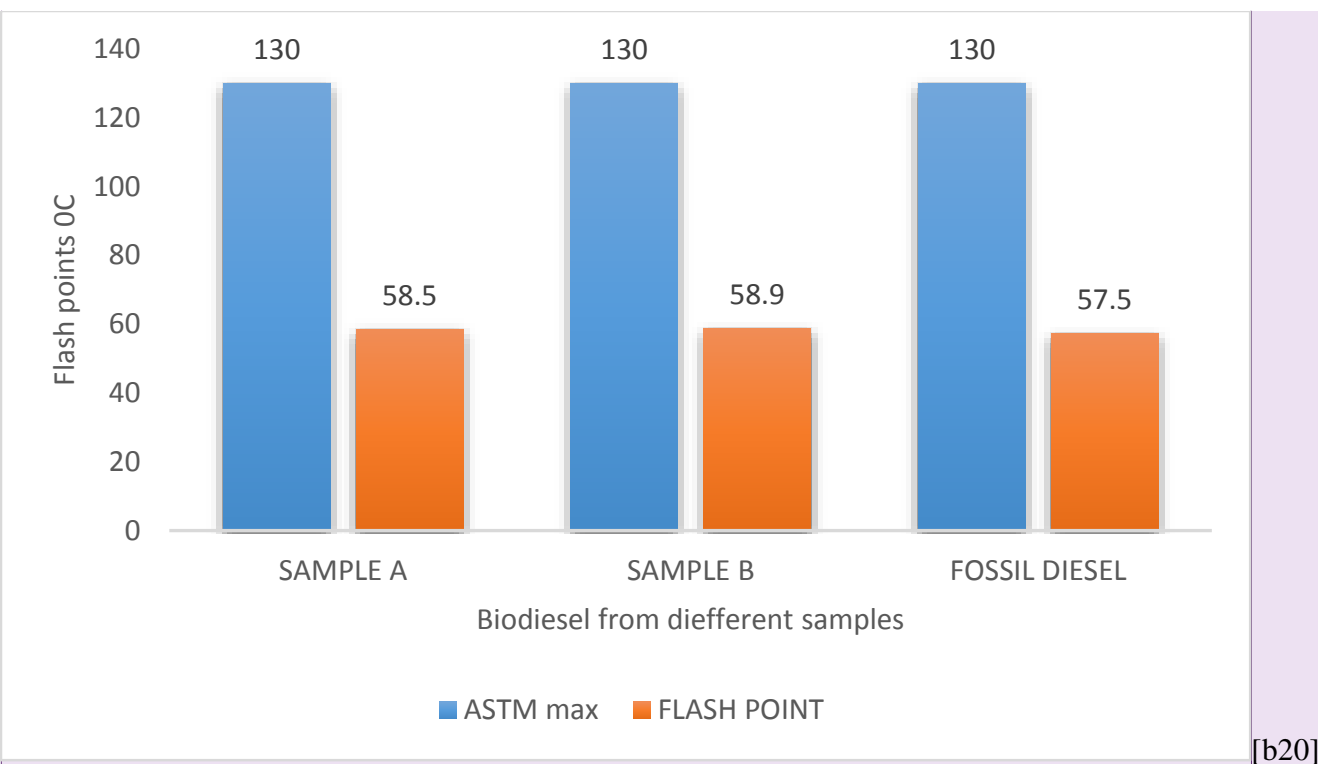

Figure 7: Flash Points of Different Biodiesel Samples

\section{Pour point}

The Pour point of biodiesel is the lowest temperature at which the fuel will still pour from its container. From figure 8, all the biodiesel values of samples A and B fall with the ASTM limits.
The results of the pour points indicate that they have good cold flow characteristics which are in line with the work of Encinar, et al. (2007) and Kaisan et al. (2017a).

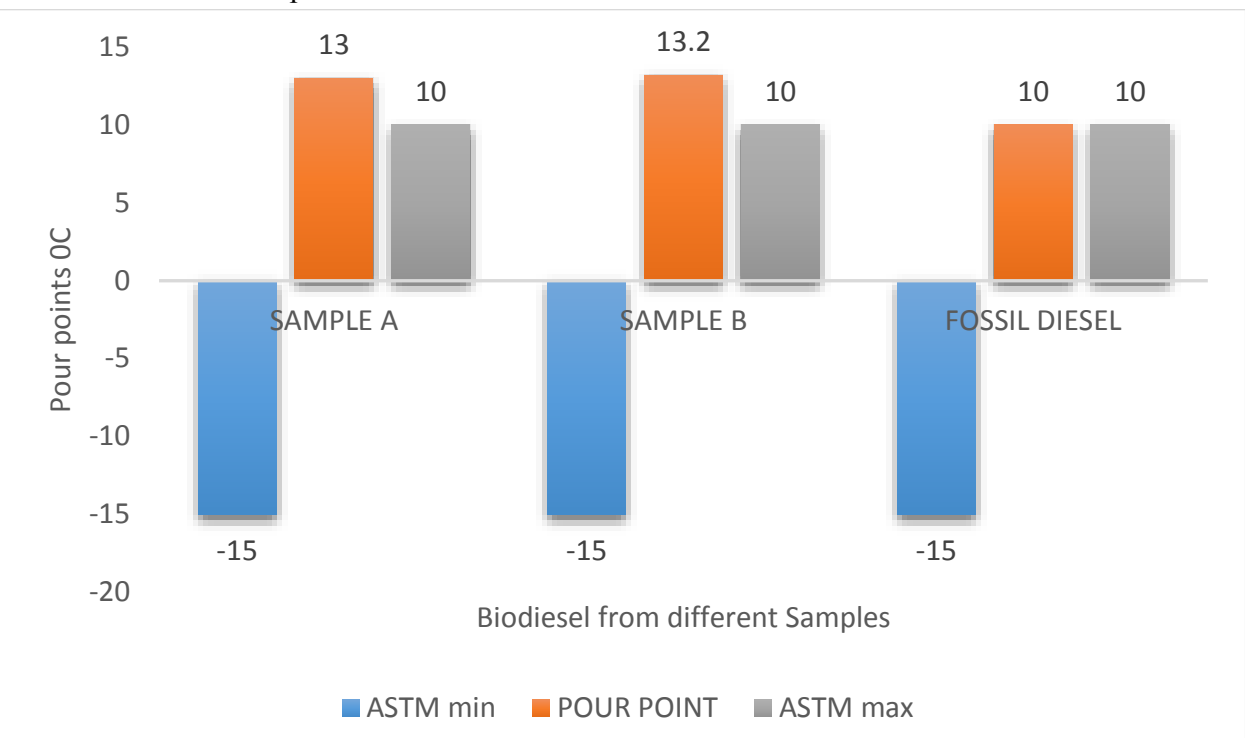

Figure 8: Pour points of different biodiesel samples

\section{Cloud point}

The cloud point is the temperature at which wax crystals first stat to form in a fuel. Figure 9 shows the cloud points for the biodiesel samples and it can be deduced that all the samples conform to the ASTM range. All the biodiesel samples have very low cloud point of below $0{ }^{\circ} \mathrm{C}$, which is similar to the work of Kaisan et al. (2017a). 


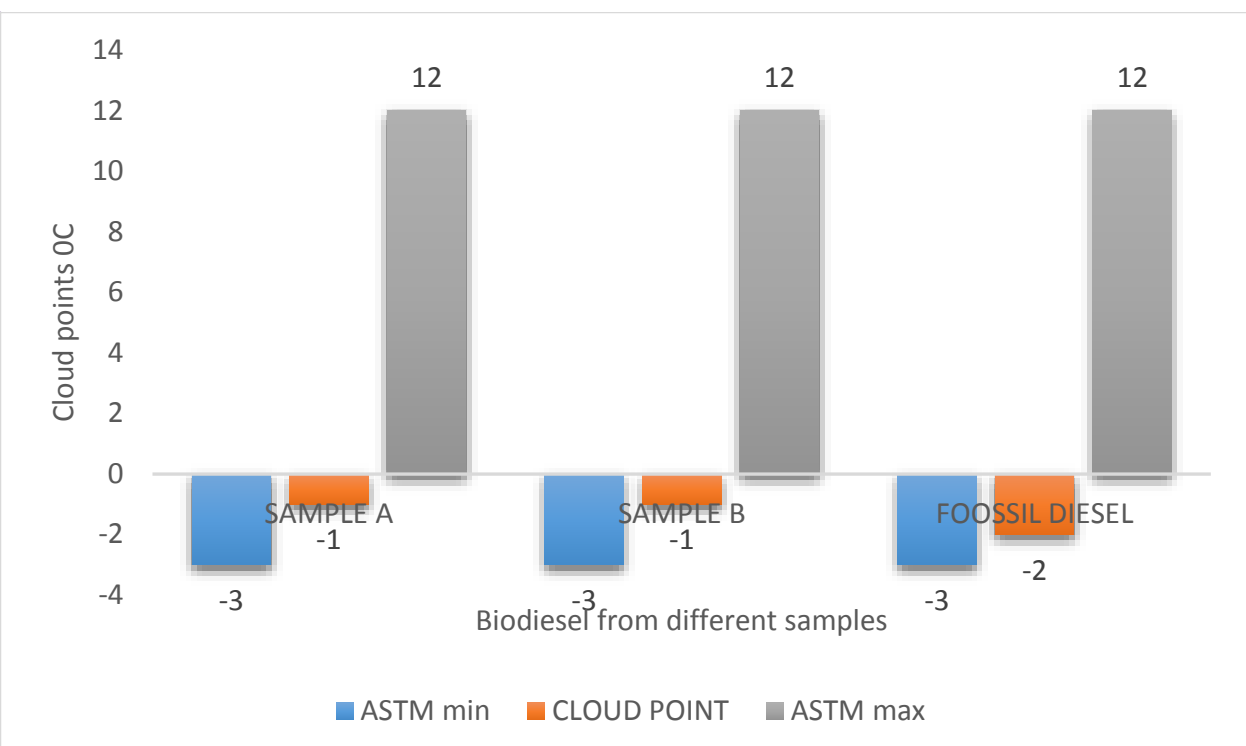

Figure 9: Cloud points of different biodiesel samples

\section{Cetane number}

Cetane number is an important parameter responsible for the ease of self-ignition behavior of fuel. Figure 10 shows the different cetane numbers of the biodiesel samples. All the samples considered conforming to the ASTM standards. The results are similar to that of Encinar et al. (2007) and Kaisan et al. (2017a).

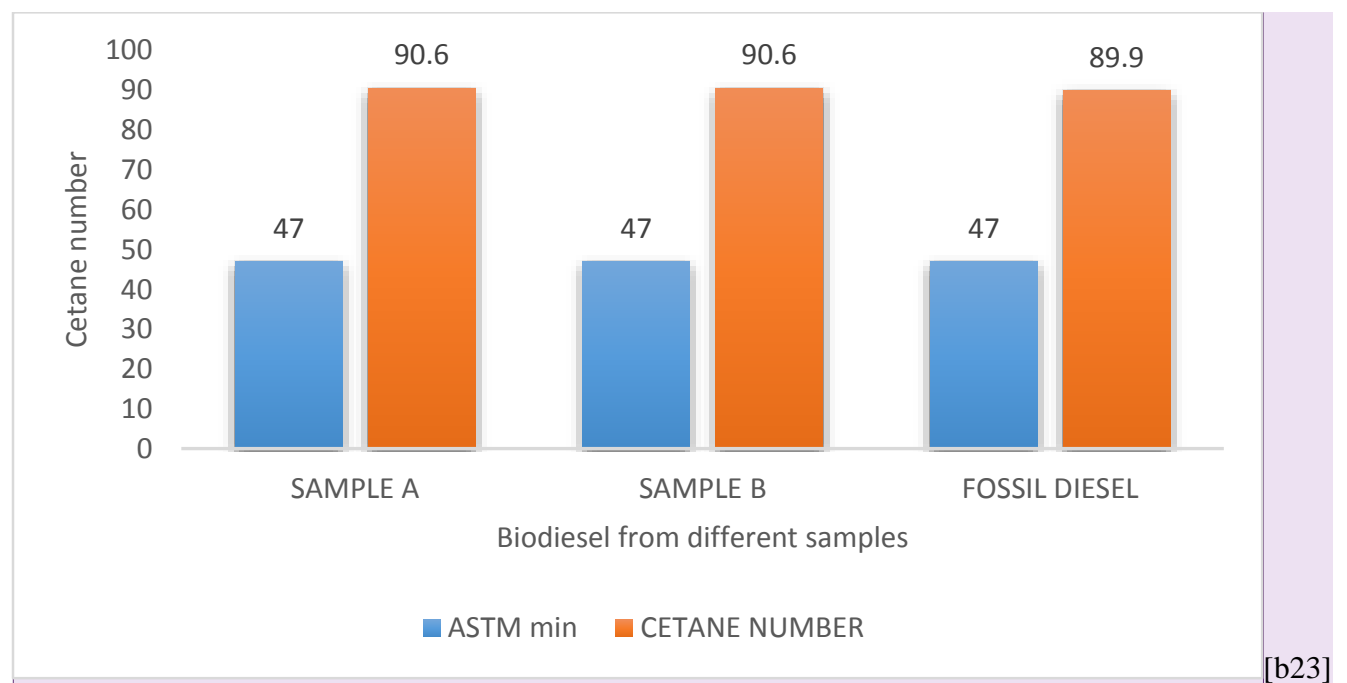

Figure 10: Cetane number of different biodiesel samples

\section{Engine performance results}

\section{Brake power}

Figures 11, 12 and 13 depict the brake powers of the biodiesel samples. A similar experiment was reported by Kaisan et al. (2017b) whose result showed that at a speed of $1000 \mathrm{rpm}$ the blend from Jatropha and diesel (B10) had the maximum brake power. From the experimental results herein presented, at a Torque of $10 \mathrm{~N}-\mathrm{m}$, the maximum brake power was that of sample A. generally, the two biodiesel samples have brake power values higher than that of the pure fossil diesel. This finding agrees with that of Anitha and Dawn, (2010). 


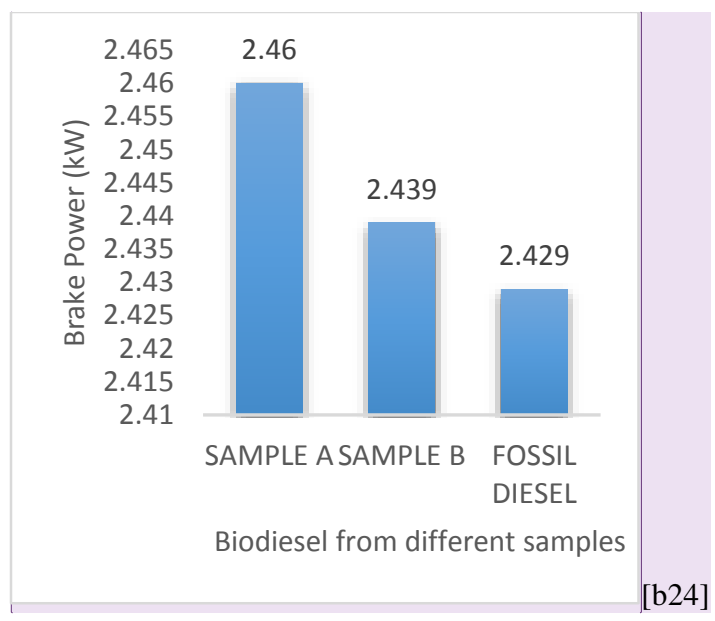

Figure 11: Brake power at $10 \mathrm{~N}-\mathrm{m}$

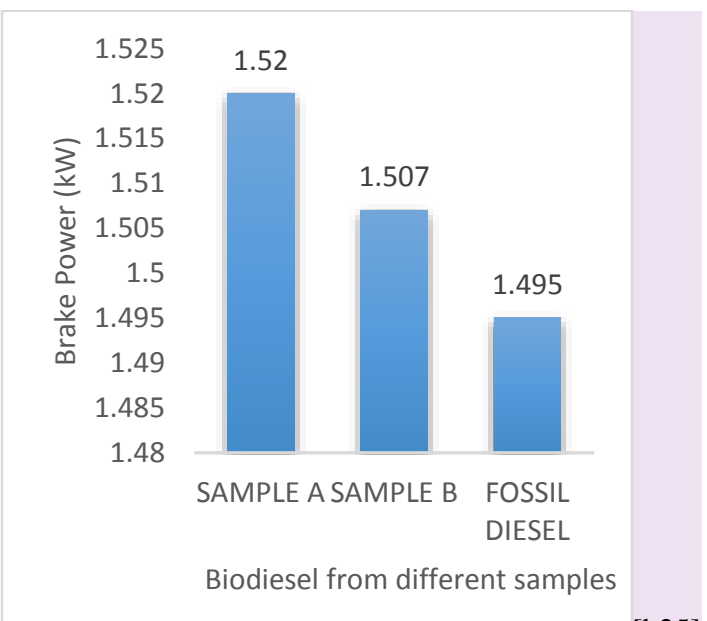

Figure 12: Brake power at $6 \mathrm{~N}-\mathrm{m}$

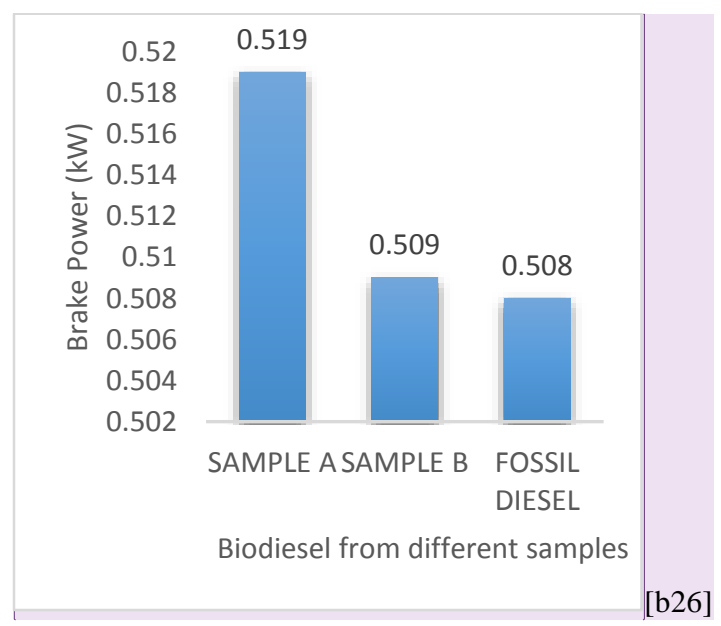

Figure 13: Brake power at $2 \mathrm{~N}-\mathrm{m}$

\section{Specific fuel consumption}

Figures 14, 15 and 16 below show the various specific fuel consumptions of the biodiesel samples and that of the pure fossil diesel. It can be seen that pure fossil diesel has a better fuel consumption rate. Also, sample A displays a good consumption rate similar to that of the fossil diesel at torques 10 and $8 \mathrm{~N}-\mathrm{m}$. The result is similar to that of Sudhir et al. (2007).

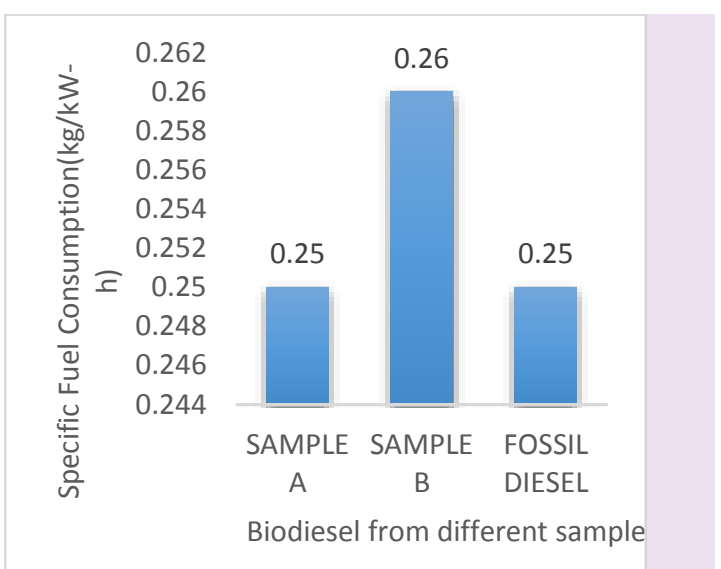

Figure 14: Specific fuel consumption at $10 \mathrm{~N}-\mathrm{m}$

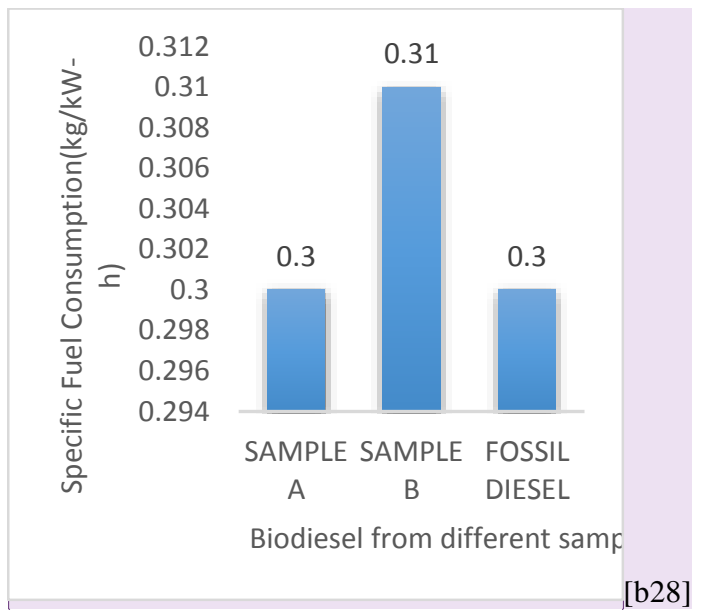

Figure 15: Specific fuel consumption at $6 \mathrm{~N}-\mathrm{m}$

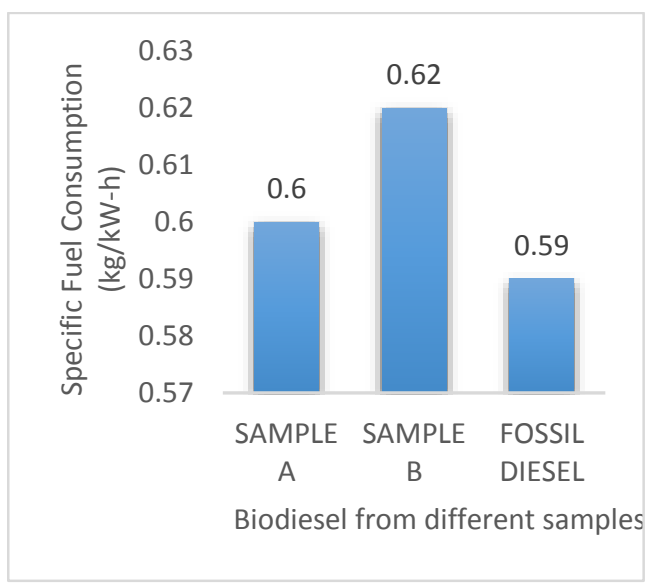

Figure 16: Specific fuel consumption at $2 \mathrm{~N}-\mathrm{m}$ 


\section{Brake mean effective pressure}

Figures 17, 18 and 19 below show the different brake mean effective pressures of the biodiesel samples and that of the pure fossil diesel. There is no significant difference in brake mean effective pressures of the biodiesel samples and that of the pure fossil diesel. The results are not in line with that of Kaisan et al. (2017a) and this is as a result of the brake powers.

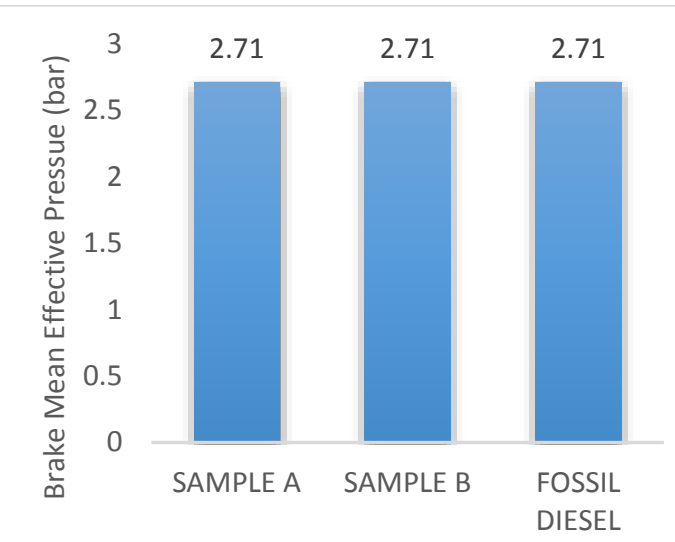

Biodiesel from different samples

Figure 17: Brake Mean Effective Pressure at 10 N-m

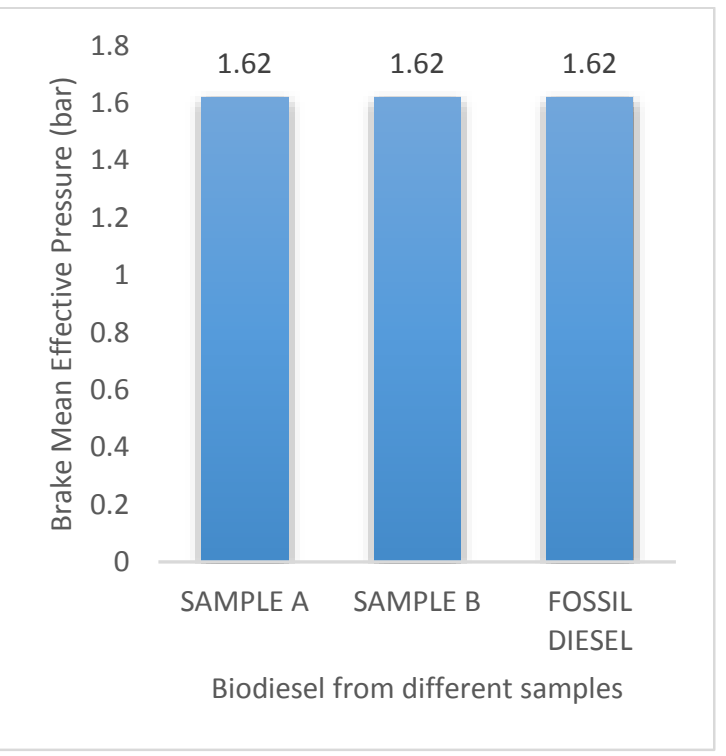

Figure 18: Brake mean effective pressure at $6 \mathrm{~N}-\mathrm{m}$

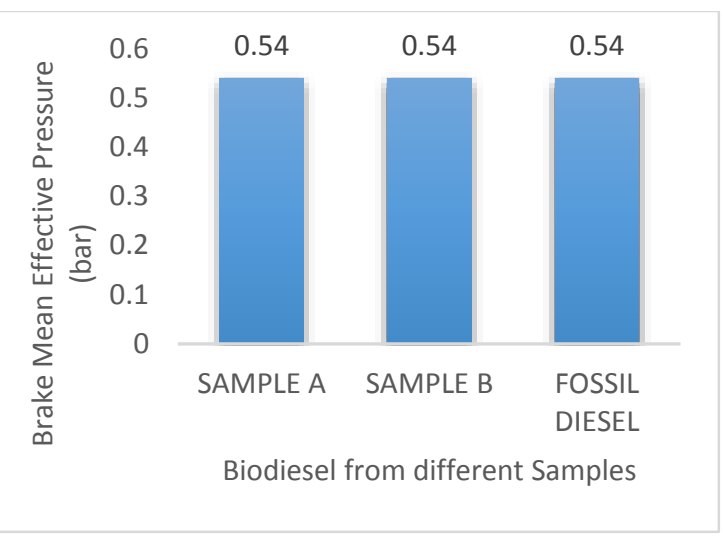

Figure 19: Brake mean effective pressure at $2 \mathrm{~N}-\mathrm{m}$

\section{Exhaust emissions results}

The exhaust gas emissions result from samples A, B and the fossil diesel are presented in the figures below:

\section{Carbon monoxide (CO) emissions}

The carbon monoxide (CO) emission is depicted in figures 20 , 21 and 22 below for the biodiesel samples and the pure fossil diesel. In figures 3.20 and 3.21 there is no variation in the $\mathrm{CO}$ emission. But, in figure 18 which is running at a torque of $2 \mathrm{~N}$ $\mathrm{m}$ indicated that biodiesel sample A emitted a higher $\mathrm{CO}$ emission than biodiesel sample B and pure fossil diesel. The result is in line with that of the work of Kaisan et al. (2017b).

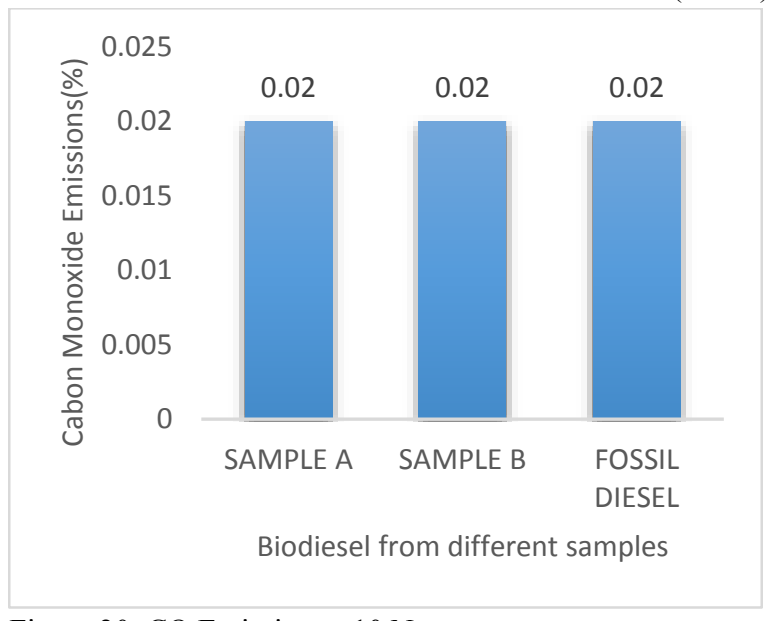

Figure 20: CO Emission at $10 \mathrm{~N}-\mathrm{m}$ 


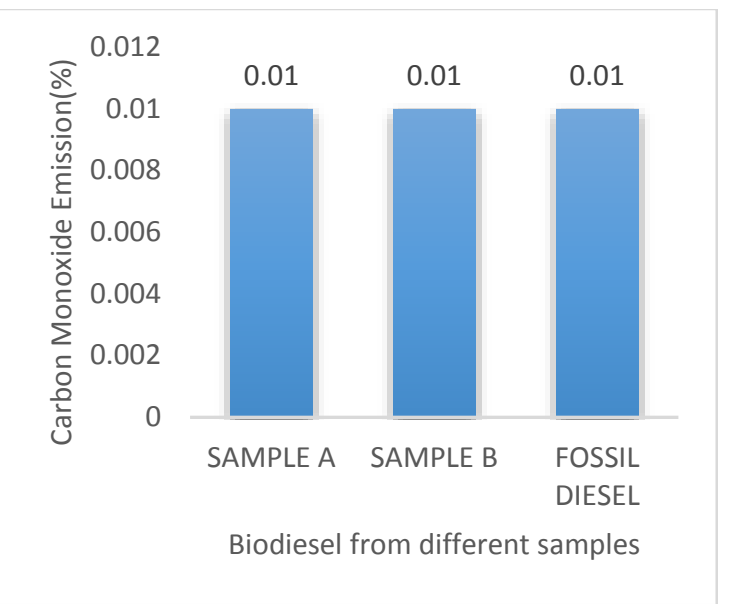

Figure 21: CO Emission at $6 \mathrm{~N}-\mathrm{m}$

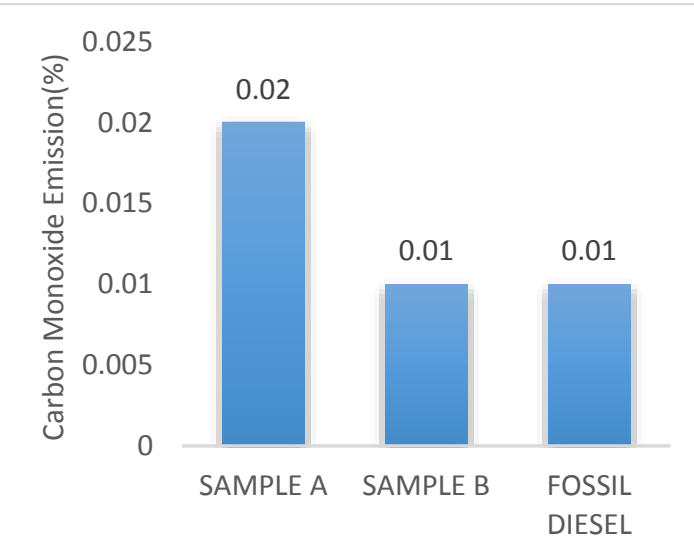

Biodiesel from different samples

Figure 22: CO Emission at $2 \mathrm{~N}-\mathrm{m}$

\section{Nitrogen oxide (NOx) emissions}

The nitrogen oxide (NOx) emissions are shown in figures 23, 24 and 25 below for the biodiesel samples and pure fossil diesel sample. In figure 3.23 it can be seen that sample A is slightly higher than that of the pure diesel while that of sample B is relatively low. In figure 24 the pure fossil diesel exhibited a higher value than that of the biodiesel samples. Although, in figure 25 the biodiesel sample B had the highest NOx emission. Some of the values are consistent with the research of Kaisan et al. (2017b) and also, that of Sudhir et al. (2007).[b29] Sample similar trend with the results of Kalam et al. (2011) and Muralidharan \& Vasudevan, (2011).

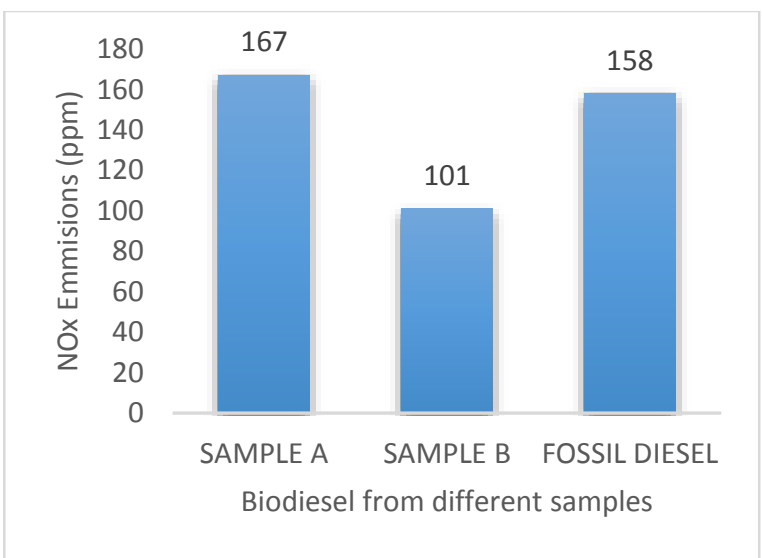

Figure 23: NOx Emission at $10 \mathrm{~N}-\mathrm{m}$

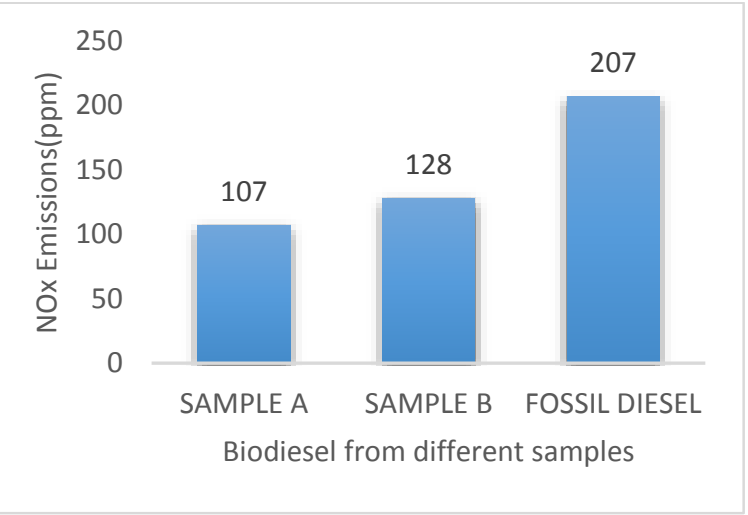

Figure 24: NOx Emission at 6 N-m

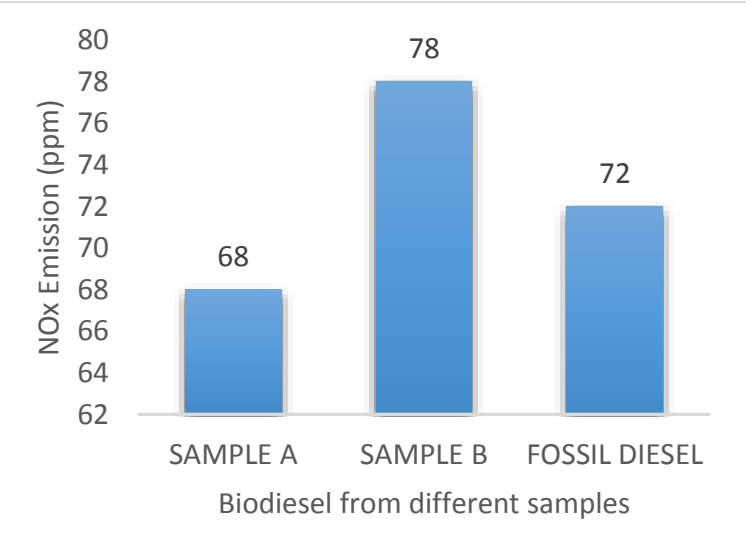

Figure 25: NOx Emission at $2 \mathrm{~N}-\mathrm{m}$

Carbondioxide $\left(\mathrm{CO}_{2}\right)$ emissions

The carbondioxide $\left(\mathrm{CO}_{2}\right)$ emission are shown in figures 26,27 and 28 below for different torques. The pure diesel sample and Sample A demonstrated the highest emissions while that of biodiesel sample B displayed a relatively low $\mathrm{CO}_{2}$ emission. This result is in line with the work of Kaisan et al., (2017b). 


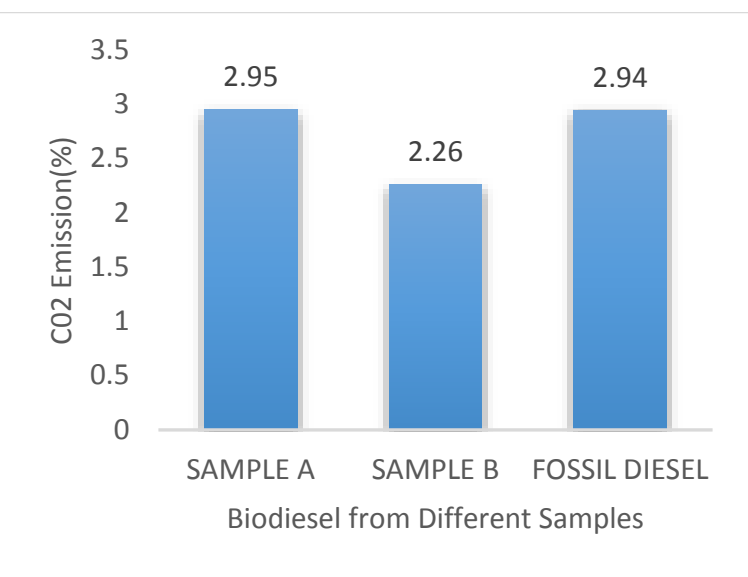

Figure 26: $\mathrm{CO}_{2}$ Emission at $10 \mathrm{~N}-\mathrm{m}$

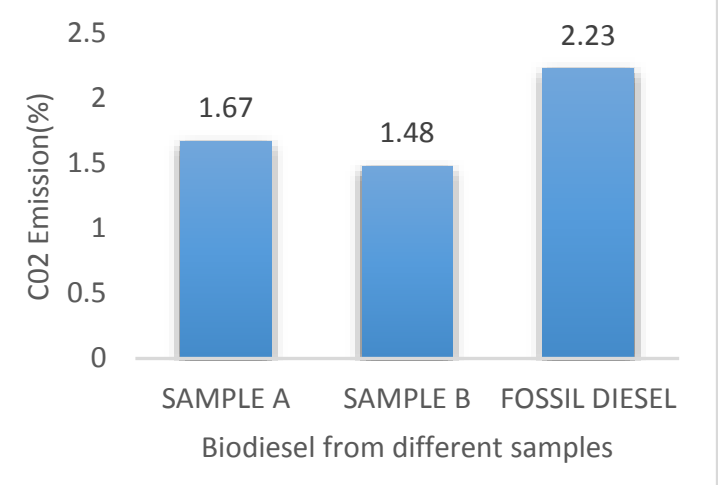

Figure 27: $\mathrm{CO}_{2}$ emission at $6 \mathrm{~N}-\mathrm{m}$

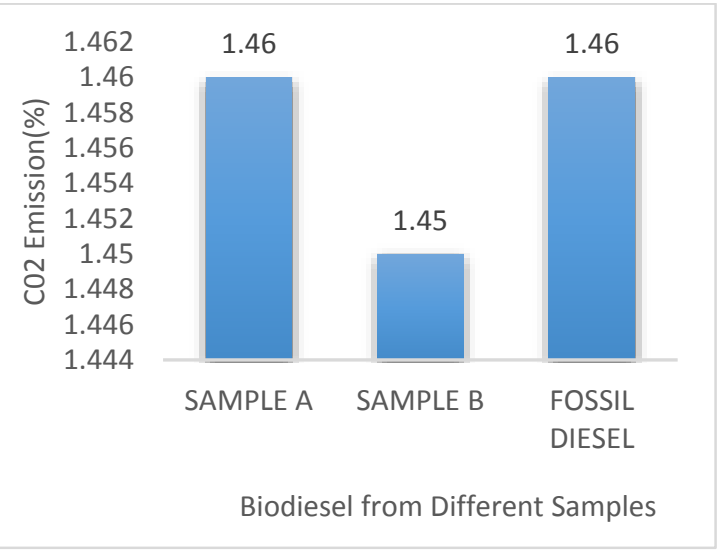

Figure 28: $\mathrm{CO}_{2}$ emission at $2 \mathrm{~N}-\mathrm{m}$

\section{Hydrocarbon (HC) emissions}

The hydrocarbon (HC) emission are shown in figures 29, 30 and 31 below for different torques. The pure diesel sample and Sample A demonstrated the highest emissions while that of biodiesel sample B displayed a relatively low $\mathrm{HC}$ emission. Some of the results are in line with the works of Mohammed and Bhargavi (2015) and sample B also agrees with the work of Shahid et al., (2012).

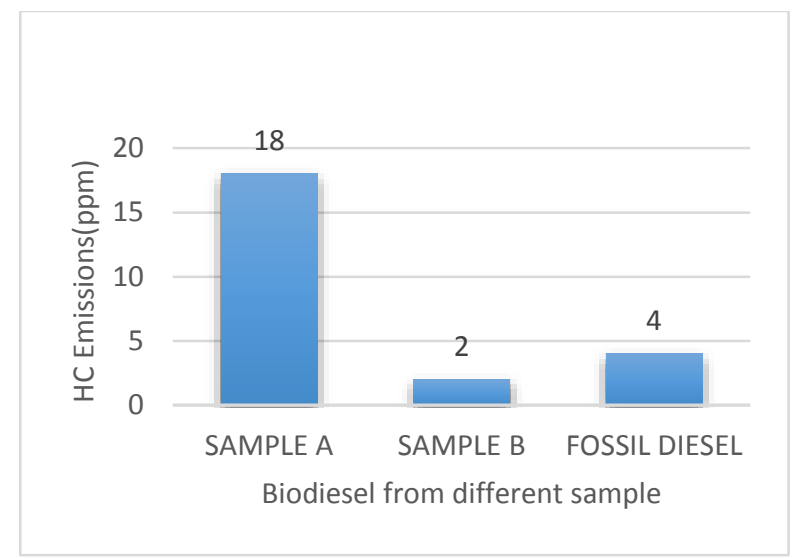

Figure 29: HC Emission at $10 \mathrm{~N}-\mathrm{m}$

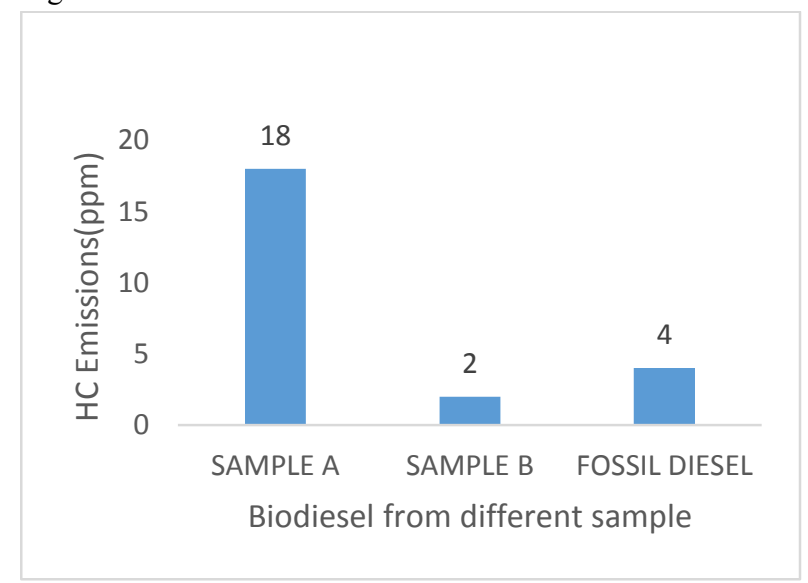

Figure 30: $\mathrm{HC}$ Emission at $6 \mathrm{~N}-\mathrm{m}$

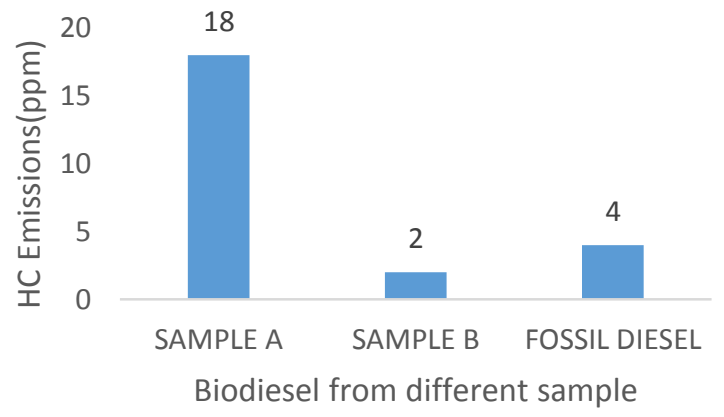

Figure 31: HC Emission at $2 \mathrm{~N}-\mathrm{m}$

\section{CONCLUSIONS}

After a carefully carried out research, conclusions were drawn that the biodiesels produced from the transesterification of used cooking oil from frying yam which yielded $87.5 \%$ and used cooking oil from frying fish which yielded $94 \%$ are viable sources of renewable energy because the trans-esterified used cooking oils met the necessary criteria for standard biodiesel as defined by the American Society for Testing and Materials ASTM D6751. It is also important to state the fact that the 
biodiesels produced from used cooking oils conform to most of the physicochemical properties standards and related past works.

Although the performance of the biodiesels produced from used cooking oils on a $165 \mathrm{~F}$ horizontal single-cylinder directinjection engine varied at different torques generally had a good brake power, better brake mean effective pressure but the specific fuel consumptions were higher than that of the pure fossil diesel especially that of the biodiesel produced from used cooking oil from frying yam which was termed as sample A.

Also, for the exhaust gas analysis carried out on the biodiesels from used cooking oils, the biodiesel produced from used cooking oil from frying yam demonstrated a higher value in terms of carbon monoxide (CO), nitrogen oxide (NOx), carbon IV oxide $\left(\mathrm{CO}_{2}\right)$ and hydrocarbon emissions while the biodiesel produced from used cooking oil from frying fish termed as sample B generally showed a reduction in values in terms of carbon monoxide (CO), nitrogen oxide (NOx), carbon IV oxide $\left(\mathrm{CO}_{2}\right)$ and hydrocarbon emissions compared to sample $\mathrm{A}$ and the pure fossil diesel.

Lastly, it can be seen that the biodiesel produced from used cooking oil from frying fish had a higher yield than the biodiesel produced from used cooking oil from frying yam and is generally better than the fossil diesel because it's environmentally friendly.

\section{REFERENCES}

Adeyemo, S. T., Ajueyitsi O. A., Adegoke, C. and Ogun, B. (1998). Fundamentals of engineering thermodynamics; A concise analysis energy transfer in engineering system. AdoEkiti: Omobala investment Ltd.

Anitha, A.; Dawn, S.S. (2010) Performance Characteristics of Biodiesel Produced from Waste Groundnut Oil using Supported Heteropolyacids. International Journal of Chemical Engineering and Applications, 1(3), 261-265.

Aydin, K., Sarıbıyı, O. Y., Özcanlı, M., Serin, H., \& Serin, S. (2010). Biodiesel Production from Ricinus Communis Oil and Its Blends with Soybean Biodiesel. Strojniski Vestnik/Journal of Mechanical Engineering, 56(12).

Bamgboye, A. I., \& Hansen, A. C. (2008). Prediction of cetane number of biodiesel fuel from the fatty acid methyl ester (FAME) composition. International Agrophysics, 22(1), 21.

Chang, I. S., Wu, J., Zhou, C., Shi, M., \& Yang, Y. (2014). A time-geographical approach to biogas potential analysis of China. Renewable and Sustainable Energy Reviews, 37, 318 333.

Eastop, T. D. and McConkey, A. (2009). Applied Thermodynamics for Engineering Technologist. (fifth edition ed.). Dorling Kindersley (India) Pvt. Ltd.
Encinar, J. M., González, J. F. A. "Rodríguez-Reinares (2007.), Ethanolysis of used frying oil. Biodiesel preparation and characterization," Fuel Processing Technology, 88:513-522.

Gashaw, A., \& Teshita, A. (2014). Production of biodiesel from waste cooking oil and factors affecting its formation: A review. International journal of renewable and sustainable energy, 3(5), 92-98.

Gerpen, J. V., Shanks, B., and Pruszko, R. (2004). Biodiesel Production Technology. Colorado: Colorado National Renewable Energy.

Han, F. F. B., \& Alrabadi, S. (2018). Using Jordan Zeolite as a Heterogeneous Catalyst for Synthesize the Used Frying Oil into Biodiesel. International Journal of Chemical Engineering and Applications, 9(5), 153.

Jaichandar, S., \& Annamalai, K. (2011). The status of biodiesel as an alternative fuel for diesel engine-An Overview. Journal of Sustainable Energy \& Environment, 2(2), 71-75.

Jacobson, K., Gopinath, R., Meher, L. C., \& Dalai, A. K. (2008). Solid acid catalyzed biodiesel production from waste cooking oil. Applied Catalysis B: Environmental, 85(1-2), 86-91.

Kaisan, M. U. (2014). Determination of Physico-Chemical Properties of Biodiesel from Wild Grape seeds Diesel Blends and their effects on the performance of diesel Engine. Ahmadu Bello University, Zaria. Zaria: Unpublished Msc. Theses.

Kaisan, M. U., Anafi, F. O., Nuszkowski, J., Kulla, D. M., \& Umaru, S. (2017a). Calorific value, flash point and cetane number of biodiesel from cotton, jatropha and neem binary and multi-blends with diesel. Biofuels.

Kaisan, M. U., Anafi, F. O., Nuszkowski, J., Kulla, D. M., \& Umaru, S. (2017b). Cold flow properties and viscosity of biodiesel from cotton, jatropha and neem binary and multiblends with diesel. African Journal of Renewable and Alternative Energy ISSN, 2006, 0394.

Kalam, M. A., Masjuki, H. H., Jayed, M. H., \& Liaquat, A. M. (2011). Emission and performance characteristics of an indirect ignition diesel engine fuelled with waste cooking oil. Energy, 36(1), 397-402.

Kawentar, W. A., \& Budiman, A. (2013). Synthesis of biodiesel from second-used cooking oil. Energy Procedia, 32, 190-199.

Kumar, D. S. (2013). Mechanical Engineering (Thermodynamics, SOM and Mechanics with Experiments) (Fourth Revised Edition ed.). New Delhi: S. K. Kataria and Sons.

Mohammed, A. R. and Bhargavi, R. (2015). Biodiesel production from waste cooking oil. Journal of Chemical and Pharmaceutical Research,7(12):670-681. 
Muralidharan, K., \& Vasudevan, D. (2011). Performance, emission and combustion characteristics of a variable compression ratio engine using methyl esters of waste cooking oil and diesel blends. Applied energy, 88(11), 3959-3968.

Ndana, M., Grace, J. J., Baba, F. H., \& Mohammed, U. M. (2013). Fourier transform infrared spectrophotometric analysis of functional groups in biodiesel produced from oils of Ricinus communis, Hevea brasiliensis and Jatropha curcas seeds. International Journal of Science, Environment and Technology, 2(6), 1116-1121.

Okere, R. (2016). Pipeline vandalism and economic recession . Lagos: The Guardian.

Physicochemical Analysis (2017). Physicochemical Analysis Free dictionary. Retrieved from http://encyclopedia2.thefreedictionary.com/Physicochemical+ Analysis on $31^{\text {st }}$ March, 2017.

Raja, S. A. (2011). Biodiesel production from jatropha oil and its characterization. Research Journal of Chemical Science, 1, 81-87.

Roger, H. (2014). Why is diesel now bad news? Retrieved from [b30] http://www.bbc.com/news/science-environment-30381223 on $18^{\text {th }}$ September, 2017.

Roos, D. (2012). Ways responsibly produced Biofuels Benefit Everyone, Retrieved from http://auto.howstuffworks.com/fuelefficiency/biofuels/5-responsibly-produced-biofuel.htm on $20^{\text {th }}$ March 2017.

Shahid, E.M.; Jamal, Y.; Shah, A.N.; Rumzan, N.; Munsha, M. (2012) Effect of Used Cooking Oil Methyl Ester on Compression Ignition Engine. Journal of Quality and Technology Management, VIII (II), 91-104.

Sudhir, C. V., Sharma, N.Y. and Mohanan, P. (2007) Potential Of Waste Cooking Oils As Biodiesel Feed Stock: Emirates Journal for Engineering Research, 12 (3), 69-75.

Zhang, Y., Dube, M. A., McLean, D. D. L., \& Kates, M. (2003). Biodiesel production from waste cooking oil: 1. Process design and technological assessment. Bioresource technology, 89(1), 116. 